\title{
The Use of Ripe Plantain (Musa spp.) and Peppercorns for Beverage Processing as a Pro-Vitamin A Carotenoid and Nutrition Catalyst
}

\author{
Mabel Kyei Kwofie1,2* (), Mabel Abrafi Sarpong', Florence Anima1, Nafisatu Bukari², \\ Oluwaseyi Adeboye ${ }^{3}$
}

${ }^{1}$ Faculty of Applied Sciences and Technology, Koforidua Technical University, Koforidua, Ghana

${ }^{2}$ Department of Human Nutrition, McGill University, Ste Anne-de-Bellevue, QC, Canada

${ }^{3}$ Department of Animal Science, McGill University, Ste Anne-de-Bellevue, QC, Canada

Email: *mayekwofie@gmail.com

How to cite this paper: Kwofie, M.K., Sarpong, M.A., Anima, F., Bukari, N. and Adeboye, O. (2020) The Use of Ripe Plantain (Musa spp.) and Peppercorns for Beverage Processing as a Pro-Vitamin A Carotenoid and Nutrition Catalyst. Food and Nutrition Sciences, 11, 1096-1106.

https://doi.org/10.4236/fns.2020.1112077

Received: November 19, 2020

Accepted: December 20, 2020

Published: December 23, 2020

Copyright $\odot 2020$ by author(s) and Scientific Research Publishing Inc. This work is licensed under the Creative Commons Attribution International License (CC BY 4.0).

http://creativecommons.org/licenses/by/4.0/

(c) (i) Open Access

\begin{abstract}
Plantain (Musa spp.) constitutes an essential food crop in both tropical and subtropical areas. The staple's nutritional value and provitamin A carotenoid potential has attracted more interest and usage. Plantain (Musa spp.) optimization into food recipes has been identified to increase patronage and minimises food wastage, due to the fruit's (pulp) high perishability nature. In this study, local over ripe plantain (Musa spp.) was sampled and used in a beverage production. The beverage was processed from pureed ripe plantain, by three days fermentation of the pureed plantain mixture, boiling, and spicing, preservation with syrup, storage, and usage. The product's processing was followed with a sensory evaluation of the new beverage on taste, appearance, color, flavour, and overall acceptability. Majority of the respondents indicated the new product was good and was well accepted. The research sought to create food diversity, encourage more usage of the crop and to highlight the nutritional values of plantain (Musa spp.) which is particularly high in provitamin A carotenoid to address Vitamin A deficiency in low resource setting communities.
\end{abstract}

\section{Keywords}

Plantain (Ripe), Pro-Vitamin A Carotenoids, Nutrients, Beverage

\section{Introduction}

Plantains and cooking bananas (Musa spp.) are staple foods grown throughout 
the tropics, it constitutes a major source of food for millions of people globally [1].

Plantain is the common name for herbaceous plants of the genus Musa. Plantains are classified formally as Musa acuminata, Musa acuminate or Musa balbisiana, balbisiana, depending on their genomic composition [2].

Plantain meets the caloric requirements of several people worldwide. Their suitability as food is that they produce crops all year round, making them more reliable all-season staple food. This is particularly important for communities living in mountainous areas or forests with inadequate food storage, transportation, and preservation technologies [2]. The raw plantain (Musa spp.) consists of nutrients, which includes proteins; carbohydrates; minerals, vitamins, monounsaturated and polyunsaturated fatty acid. These nutrients make plantain a nutritious food source that addresses both the macro and micro-nutrient needs of growing populations and prevents nutrient deficiencies, most especially Vitamin A [3]. Greater than $80 \%$ of the sources of Vitamin A in developing countries are obtained from plant sources in the form of provitamin A carotenoids of which the body later converts into retinol (Vitamin A) [4]. Vitamin A is particularly necessary for children below five and women of reproductive ages for good vision, reproductive health and immune resistance to infections and diseases [5] [6]. A recent study indicated that, daily intake of ripe (yellow) plantain of 250 g meets $7.6 \%$ and $71.8 \%$ DRI of Vitamin A of infants below (5) five years of age, whereas $500 \mathrm{~g}$ daily intakes of ripe plantain meets the Vitamin A DRI of $8.7 \%$ and $81 \%$ of women of childbearing ages respectively [1]. Plantain (Musa spp.) found in the tropical areas of Africa contains provitamin A carotenoids which range from 3.89 to $18.75 \mathrm{mg} / \mathrm{g} \mathrm{fw}$ [7] moreover, researches indicate that orange-fleshed plantains (Musa spp.) have significantly higher $(61.19 \mathrm{mg}$ ) b-carotene/g fw provitamin A carotenoid [8]. An in-vitro bio-accessibility study conducted by [7] on ripe plantain revealed that, following processing, the provitamin A available for absorption in ripe plantain-derived dishes (16\% - 27\%) was higher than those found in common root tubers.

Plantains contain less sugar and are firmer when compared to dessert banana [9]. While dessert bananas can be eaten raw, plantains need to be cooked or processed, and are usually processed in unripe or overripe form. Plantain and banana have a difference of $15 \mathrm{~g}$ of starch per $100 \mathrm{~g}$ of $\mathrm{DW}$, even with same genotype (AAB) [10]. A standard plantain contains about 220 calories and is a good source of dietary fibre [3].

Plantain fruits (Musa spp.) may be consumed unripe (green) by cooking, and ripe or yellow [11]. It is also used in preparation of other traditional dishes ranging from plantain chips, flour, fritters, "akara" in Nigeria. In Africa and some parts of the world, large quantities of beer are brewed from plantain (Musa spp.). It has a low alcoholic rate but high vitamin content, especially provitamin A and is therefore of significant importance in nutrition. Other products derived from plantain are figs (dried slices of ripe plantain), powder 
(ground form of ripe plantain), flakes, juice, and puree ([12] [13] [14]. Plantain, the subject of this study is also well used in Ghana in the preparation of local dishes such as ampesi, roasted plantain, "tatale" and "kakro", it can be fried or roasted and eaten with cooked beans or groundnut. Plantain can be used for jam, marmalades, juice, and vinegar. Some other forms of usage include handcrafts from the leaves and fiber, ropes, peels for animal feeds, and leaves for wrapping foodstuff [14] [15].

This paper aimed to produce nutritious beverage using yellow or ripe plantain (Musa spp.), which contain naturally occurring pro-vitamin A with other nutrients and to conduct sensory evaluation of the new beverage developed to determine its acceptability by respondents.

\section{Plantain (Musa spp.) Food Value Chain}

The food chain cycle from farms to table constitutes the transfer of staple foods such as plantain. Due to plantain fruits perishable nature, their post-harvest losses fluctuate among different countries, which largely depends on the market chains organization and consumption modes. Hence, there are limited to no data on post-harvest losses in several plantains producing countries [16]. Post-harvest losses assessment of plantain is difficult because both the green plantains (unripe) and the yellow (overripe) fruits are consumed. Nonetheless, issues such as limited transportation and distribution facilities in production regions, harvest at maturity close to fruit ripening, and poor storage conditions often depreciate plantain's (Musa spp.) quality leading to post-harvest losses [16]. Nevertheless, no use is put to over ripe plantain in its almost deplorable state, it is either thrown away or sold at a cheaper rate with no economic significance. More so, although the plantain (Musa spp.) might be over ripe and less attractive, it is nutritious, and beverages can be made from it. It can meet nutritional needs especially vitamin A deficiency which is prevalent in low resources settings and developing countries and prevent food wastage, insecurity, and food scarcity. Young infants and women are generally affected by Vitamin A deficiency which impedes human developmental potential and affects economic and social development [17]. Dietary diversification, food fortification, supplementation, food modification and disease control measures are methods often employed in managing Vitamin A deficiency [18]. Dietary modification approaches and dietary diversification are reportedly the most feasible, sustainable, economically, and culturally acceptable approaches that require altering food production practices, household methods for preparing, processing indigenous foods and its intake patterns [19].

\section{Nutritional Composition of Plantain}

Table 1 shows the lists of proximate, minerals and vitamins composition in $100 \mathrm{~g}$ plantain. According to [20], ripe plantain gave yields higher in starch than the unripe plantain. The starch extract in both variety differs: ripe plantain starch has: ash $(0.95 \%)$, fat $(0.403 \%)$ and protein $(0.325 \%)$ while the unripe plantain starch contents consist of: ash (1.09\%) fat $(0.27 \%)$, protein $(0.64 \%)$. A 
study by [21] on the proximate chemical composition of the amino acids and carbohydrate components of ripe and green plantain (Musa spp.), showed the overall quality of sugars in the plantains substantially increased through ripening from $3.0 \%$ to $31.6 \%$ in the peel (skin) and from $1.3 \%$ to $17.3 \%$ in the fruit (pulp), respectively.

Table 1. Nutritional values of plantain per $100 \mathrm{~g}$ of edible portion (USDA, 2016).

\begin{tabular}{|c|c|c|}
\hline Nutrient & Unit & Amount \\
\hline \multicolumn{3}{|l|}{ Proximate } \\
\hline Water & g & 65.30 \\
\hline Carbohydrates & g & 31.89 \\
\hline Protein & g & 1.30 \\
\hline Fats & g & 0.37 \\
\hline Dietary Fibre & g & 2.30 \\
\hline Energy & KJ & 510.00 \\
\hline \multicolumn{3}{|l|}{ Vitamins } \\
\hline Vitamin A & $\mu \mathrm{g}$ & 56.00 \\
\hline Beta-Carotene & $\mu \mathrm{g}$ & 457.00 \\
\hline Vitamin K & $\mu \mathrm{g}$ & 0.70 \\
\hline Vitamin E & $\mathrm{mg}$ & 0.14 \\
\hline Thiamine (B1) & $\mathrm{mg}$ & 0.052 \\
\hline Riboflavin (B2) & $\mathrm{mg}$ & 0.054 \\
\hline Niacin (B3) & $\mathrm{mg}$ & 0.686 \\
\hline Vitamin B6 & $\mathrm{mg}$ & 0.299 \\
\hline Folate & $\mu \mathrm{g}$ & 22.00 \\
\hline Pantothenate & $\mathrm{mg}$ & 0.26 \\
\hline Choline & $\mathrm{mg}$ & 13.50 \\
\hline Vitamin C & $\mathrm{mg}$ & 18.40 \\
\hline \multicolumn{3}{|l|}{ Minerals } \\
\hline Sodium & $\mathrm{mg}$ & 4.00 \\
\hline Potassium & $\mathrm{mg}$ & 499.00 \\
\hline Calcium & $\mathrm{mg}$ & 3.00 \\
\hline Magnesium & $\mathrm{mg}$ & 37.00 \\
\hline Phosphorus & $\mathrm{mg}$ & 34.00 \\
\hline Iron & $\mathrm{mg}$ & 0.60 \\
\hline Zinc & $\mathrm{mg}$ & 0.14 \\
\hline
\end{tabular}




\section{Plantain (Musa spp.) Fermentation}

Fermentation of foods is one of the most important technologies used in pre-industrial societies to transform agricultural and wild food products into edible and nutritional products. The fermentation process is associated with a variety of attributes, some of the most important being enhancement of foods nutritional quality, preservation, decrease in food spoilage and harmful attributes, including harmful bacteria [22]. Fermentation procedures are often locally acquired and maintained and easily made with less technology. Fermented foods are necessary for survival in places of food insecurity, locally fermented foods are generally cheap, and practiced worldwide [22]. In this study, basic fermentation strategies are employed for the preparation/processing of the ripe plantain beverage. The pureed pulp of plantain (Musa spp.) was fermented for three days.

\section{Materials and Methods}

\section{Materials}

The materials needed for this study included ripe plantain, sugar, and peppercorns. The plantain (Musa spp.) in a very ripe form on a scale of ripeness stage (7) seven, and the other ingredients required for the preparation of the plantain and peppercorn beverage were purchased from the local market of Koforidua municipality, eastern region, Ghana. The product preparation and sensory evaluation were conducted at the campus of Koforidua Technical University, Hospitality Department, Ghana. Table 2 shows the ingredient and their quantities to produce the beverage.

\section{Methods}

Over-ripe plantain was washed and peeled. The plantain was weighed and put into a clean bowl. The overripe plantain was then mashed into a smooth paste (pureed). Water was added and left to ferment for three days. After the fermentation was completed, the plantain mixture was boiled for $30 \mathrm{mins}$, and strained. The strained plantain mixture was re-boiled for $30 \mathrm{mins}$, and peppercorns were added as a spice to improve the flavor. Syrup made from sugar was poured into the mixture to act as a preservative. The new product was left to cool. The finished ripe plantain drink/beverage was transferred into individual sterilized bottles and the lids sealed. The new product (ripe plantain beverage/drink) was then kept in a refrigerator to chill and made ready for service. Below is the new product preparation flow chart (Figure 1).

Table 2. Plantain beverage Ingredients and their quantities.

\begin{tabular}{ccc}
\hline Ingredients & Unit & Quantity \\
\hline Over-ripe plantain & $\mathrm{kg}$ & 3 \\
Water & litres & $11 / 2$ \\
Syrup & $\mathrm{oz}$ & 8 \\
Peppercorns & singles & 10 \\
\hline
\end{tabular}




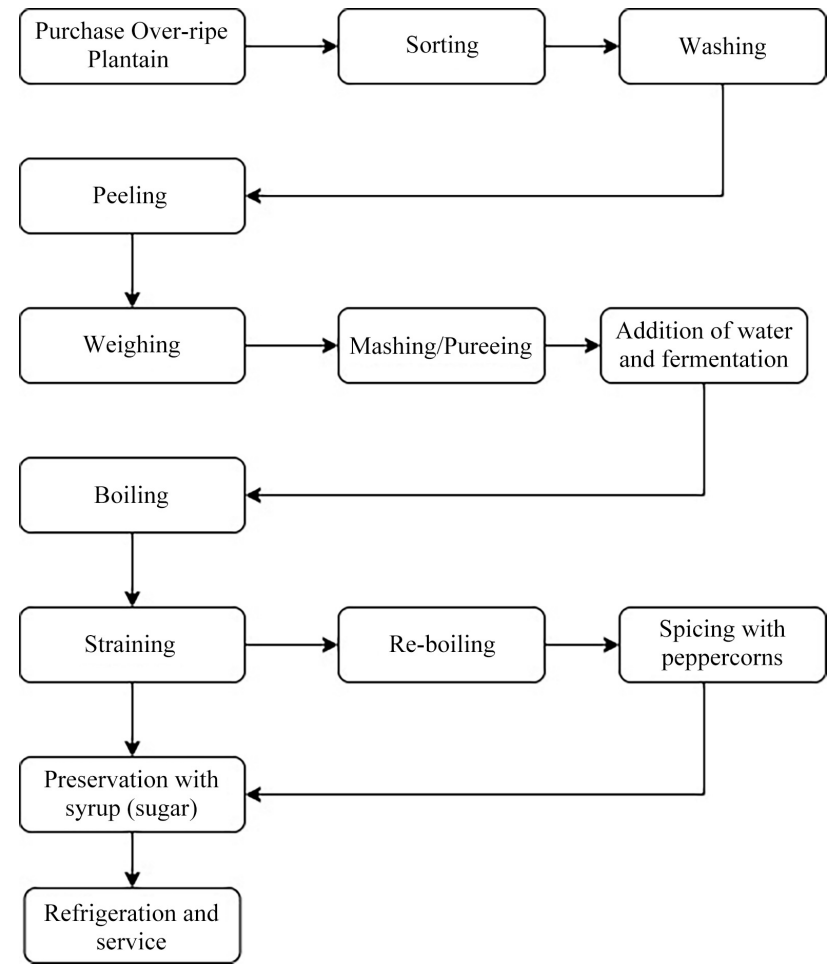

Figure 1. Processing of plantain beverage flow chart.

\section{Sensory Analysis of Overripe Plantain Beverage}

Sensory evaluation constitutes a vital phase in new product development and experimentations, the new product should be able to appeal to the perceived respondents (users) sensibility [23]. Sensory evaluation prompts, quantify, evaluate, and explain reactions to the attributes of foods and raw materials as they are perceived by the senses of smell, taste, touch, sight, and hearing [24]. The sensory evaluation was on ripe plantain and peppercorns beverage. A total number of fifty (50) panellists were selected among students at Koforidua Technical University, Koforidua, Ghana. The recruitment criteria were that the panellists (respondents) were knowledgeable of plantain and its food products (including other locally made beverages), have no allergy to the plantain fruits (pulps), and accept to participate in the study (test). The sensory characteristics assessed in this study are taste, sight, flavour, appearance, and colour.

\section{Results and Discussions}

\section{Product description}

The product ripe plantain beverage was made from overripe plantain, peppercorns, and sugar (Figure 2).

\section{Sensory Analysis of Overripe Plantain Beverage Presentation}

Figure 3(a) presents the results of the sensory evaluation on taste. The results indicate that, out of the 50-respondents sampled, 35 representing $70 \%$ responded that the new plantain beverage was very pleasant, 10 respondents representing $20 \%$ chose pleasant, while 2 respondents representing $10 \%$ selected quite plea- 
sant, none of the respondents scored the new product not tasty. The results give evidence that most of the respondents liked the new plantain and peppercorns beverage.

Figure 3(b) summarizes the results of the new plantain beverage appeal to sight. Out of the 50 respondents, 17 representing, that is $34 \%$ of the respondents indicated the new beverage was very appealing, 26 representing being $52 \%$ chose appealing, 7 respondents representing $14 \%$ selected quite appealing while none of the respondents responded to not appealing. The results suggest the new product was acceptable and appealing by sight.

Figure $3(\mathrm{c})$ provides results on the flavor of the new plantain beverage. Half of the respondents, constituting $50 \%$ of the respondents responded that the product was very nice, $42 \%$ chose nice, $8 \%$ indicated the new product was quite nice and none of the respondents chose not nice. The results confirm that majority of the respondents found the flavor of the new product to be very nice.

Results from the Figure 3(d) provide scores on the appearance of the new plantain and peppercorn beverage. According to the results, 21 of the respondents responded that the new plantain was very good which represents $42 \%$, whiles 23 respondents, representing $46 \%$, chose good, and 6 of the respondents selected quite good this represents $12 \%$, none chose not good. These results demonstrate that majority of the respondents found the new product as good.

Figure 3(e) shows results on the color of the new plantain beverage. The scores shows $23(46 \%)$ of the respondents indicated the new beverage is very colorful, $15(30 \%)$ of respondents indicated the beverage was colorful, whiles 12 (24\%) of the respondents responded to quite colorful, none of the respondents answered to not colorful. The results imply the color of the new product was acceptable.

Table 3 shows results on the overall acceptability of the new beverage. All the panel (respondents) indicated they liked the new beverage which represents 50 $(100 \%)$ of the respondents. This means the new product is well acceptable as a beverage.

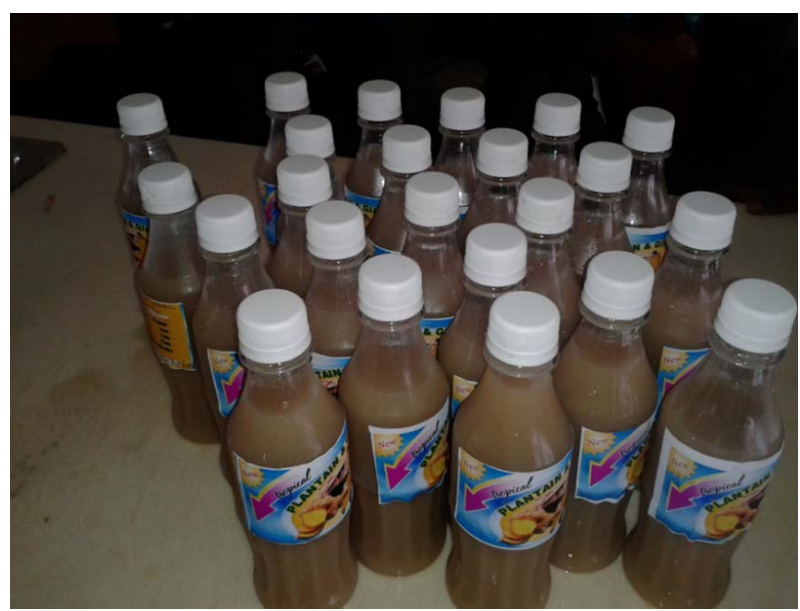

Figure 2. Bottled ripe plantain and peppercorns beverage. 


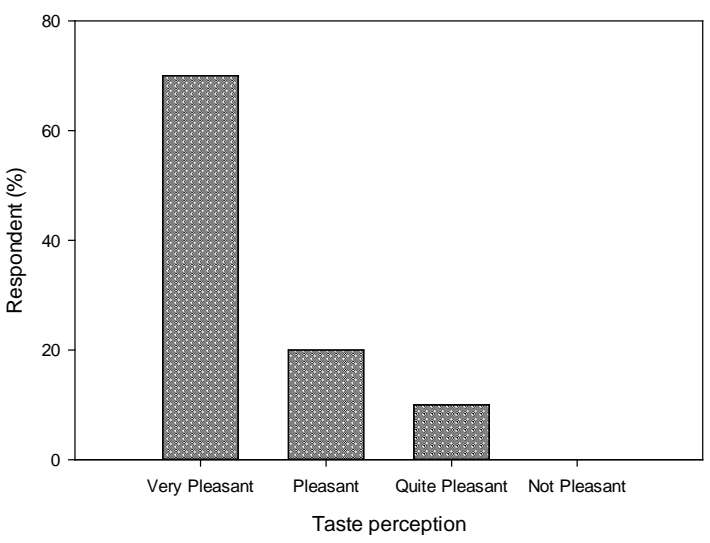

(a)

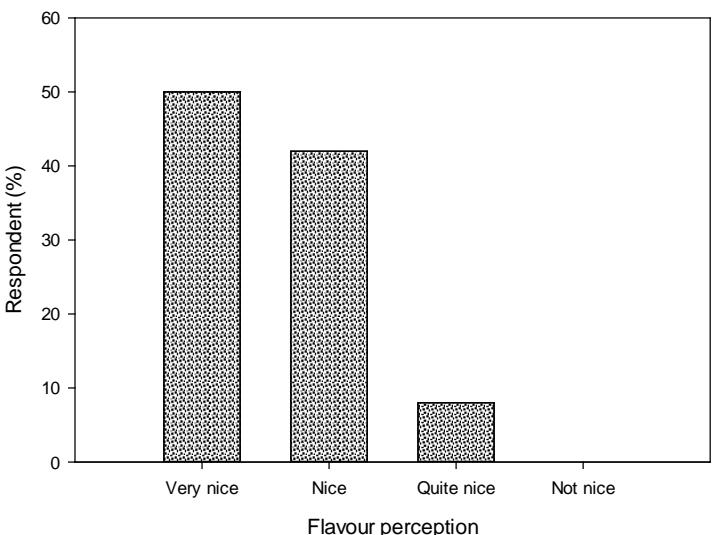

(c)

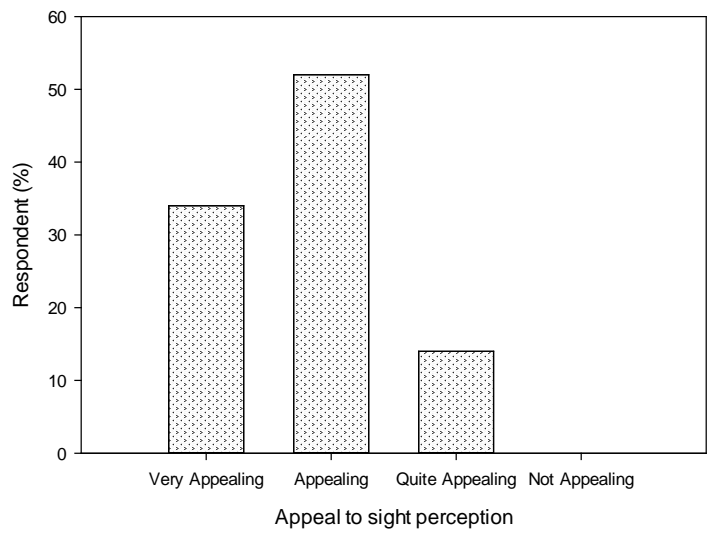

(b)

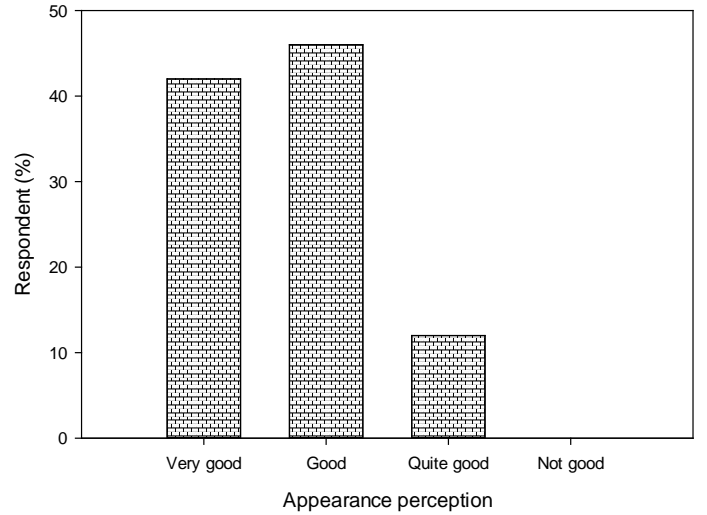

(d)

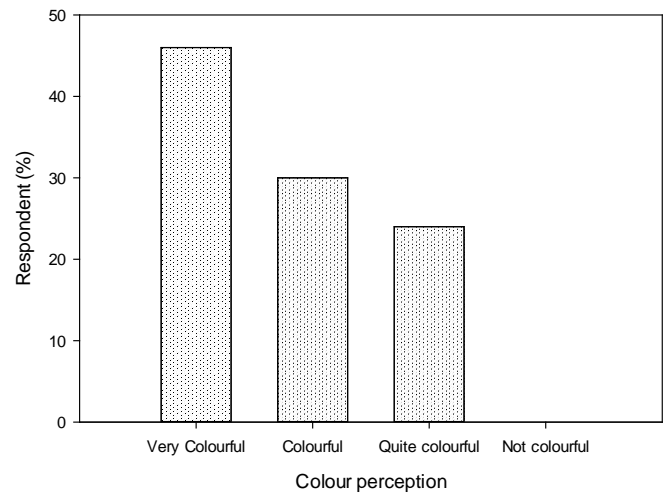

(e)

Figure 3. Sensory evaluation of over ripe plantain drink on (a) taste (b) appeal by sight (c) flavor (d) appearance (e) colour.

Table 3. Sensory evaluation of over ripe plantain drink on overall acceptability.

\begin{tabular}{ccc}
\hline Attributes & Number of respondents $(\mathbf{n}=\mathbf{5 0})$ & Percentage $(\%)$ \\
\hline Like & 50 & 100 \\
Dislike & 0 & 0 \\
Not at all & 0 & 0 \\
Total & 50 & 100 \\
\hline
\end{tabular}

Source: Field Survey. 


\section{Discussion}

The plantain and peppercorn beverage is an innovative product. Generally, drinks and beverages are frequently consumed in tropical areas due to the climate. As per the various results from the sensory evaluation, the parameters of taste, color and flavor were scored by the panel as very pleasant, very nice and very colorful. This could be attributed to the fact that the beverage was made from plantain which is unusual to most of the respondents, since soft over ripe plantain has very low significant value as a food commodity, this might have positively influenced the respondent's perception about the new beverage as being unique. Similarly, the appearance and appeal to sight of the plantain and peppercorn beverage were both scored as good because the carotenoid present in the beverage gave it an orange-like yellowish color of which the respondents were comfortable with.

\section{Conclusion}

In this research, over ripe plantain (Musa spp.) and peppercorns were utilised in a beverage preparation and processing. The purpose of the study is to encourage dietary diversity, reduce food wastage and to promote the incorporation of plantain and overripe plantain into our diets for its nutritional attributes (nutrition education). A sensory evaluation was conducted on fifty (50) respondents on the new product developed from overripe plantain regarding the taste, appearance, colour, flavour, and overall acceptability of the beverage. Majority of the respondents indicated the new beverage was very good, and they readily received it. The study outcome suggests plantain (Musa spp.) can be put to several beneficial use in modern food preparation and processing. The study result is an indication that individuals and households will readily accept new developed food products (recipes) from plantain. As more recipes and education are created about plantain (Musa spp.), which has naturally occurring pro-vitamin A carotenoids and other nutrients, more patronage and usage of the fruit (pulp) will be observed and consequently, reduce nutritional and vitamin A (retinol) deficiency rate, most especially in developing countries for a healthy life.

\section{Acknowledgements}

The authors express gratitude to the respondents (panel), Mrs. Joyce Quaye and the Hospitality Department of Koforidua Technical University, Ghana.

\section{Conflicts of Interest}

The authors declare no conflicts of interest regarding the publication of this paper.

\section{References}

[1] Blomme, G., Ocimati, W., Nabuuma, D., Sivirihauma, C., Davey, M., Buah, S., Van den Bergh, I., Vutseme, L., Bahati, L. and Ekesa, B. (2019) Pro-vitamin A carotenoid 
content of 48 plantain (Musa AAB genome) cultivars sourced from eastern Democratic Republic of Congo. Journal of the Science of Food and Agriculture, 100, 634-647. https://doi.org/10.1002/jsfa.10058

[2] Nelson, S., Ploetz, R. and Kepler, A. (2006) Musa Species (Banana and Plantain). Species Profiles for Pacific Island Agro Forestry, 22, 1-28.

[3] United States Department of Agriculture (2016) Food Central Data (100g Plantain, Ripe Plantain). United States Department of Agriculture, Washington DC.

[4] van den Berg, H., Faulks, R., Granado, H.F., Hirschberg, J., Olmedilla, B., Sandmann, G., Southon, S. and Stahl, W. (2000) The Potential for the Improvement of Carotenoid Levels in Foods and the Likely Systemic Effects. Journal of the Science of Food and Agriculture, 80, 880-912.

https://doi.org/10.1002/(SICI)1097-0010(20000515)80:7<880::AID-ISFA646>3.0.CO ;2-1

[5] Maziya-Dixon, B.B., Akinyele, I.O., Sanusi, R.A., Oguntona, T.E., Nokoe, S.K. and Harris, E.W. (2006) Vitamin A Deficiency Is Prevalent in Children Less than 5 y of Age in Nigeria. The Journal of Nutrition. 136, 2255-2261.

https://doi.org/10.1093/jn/136.8.2255

[6] World Health Organisation (2009) Global Prevalence of Vitamin A Deficiency in Populations at Risk 1995-2005: WHO Global Database on Vitamin A Deficiency. World Health Organisation, Geneva.

[7] Ekesa, B., Nabuuma, D., Blomme, G. and Van den Bergh, I. (2015) Provitamin A Carotenoid Content of Unripe and Ripe Banana Cultivars for Potential Adoption in Eastern Africa. Journal of Food Composition and Analysis, 43, 1-6. https://doi.org/10.1016/j.jfca.2015.04.003

[8] Englberger, L., Darnton-Hill, I., Coyne, T., Fitzgerald, M.H. and Marks, G.C. (2003) Carotenoid-Rich Bananas: A Potential Food Source for Alleviating Vitamin A Deficiency. Food and Nutrition Bulletin, 24, 303-318. https://doi.org/10.1177/156482650302400401

[9] Mbabazi, R. (2015) Molecular Characterisation and Carotenoid Quantification of Pro-Vitamin A Biofortified Genetically Modified Bananas in Uganda. Queensland University of Technology, Brisbane.

[10] Soares, C.A., Helena Gonçalves Peroni-Okita, F., Borba Cardoso, M., Shitakubo, R., Maria Lajolo, F. and Rosana Cordenunsi, B. (2011) Plantain and Banana Starches: Granule Structural Characteristics Explain the Differences in Their Starch Degradation Patterns. Journal of Agricultural and Food Chemistry, 59, 6672-6681. https://doi.org/10.1021/jf201590h

[11] Taiwo, K. and Adeyemi, O. (2009) Influence of Blanching on the Drying and Rehydration of Banana Slices. African Journal of Food Science, 3, 307-315.

[12] Ngoh Newilah, G., Tchango Tchango, J., Fokou, É. and Etoa, F.-X. (2005) Processing and Food Uses of Banana and Plantains in Cameroon. Fruits, 60, 245-253. https://doi.org/10.1051/fruits:2005031

[13] Zandonadi, R.P., Braz Assunção Botelho, R., Gandolfi, L., Selva Ginani, J., Martins Montenegro, F. and Pratesi, R. (2012) Green Banana Pasta: An Alternative for Gluten-Free Diets. Journal of the Academy of Nutrition and Dietetics, 112, 1068-1072. https://doi.org/10.1016/j.jand.2012.04.002

[14] Adi, D.D., Oduro, I., Tortoe, C., Miezah Kwofie, E. and Kofi Simpson, B. (2018) Physicochemical Characteristics and Microbiological Quality of Senescent Plantain Products. Cogent Food \& Agriculture, 4, Article ID: 1441596. https://doi.org/10.1080/23311932.2018.1441596 
[15] Agama-Acevedo, E., Sañudo-Barajas, J.A., Vélez De La Rocha, R., González-Aguilar, G.A. and Bello-Peréz, L.A. (2016) Potential of Plantain Peels Flour (Musa paradisiaca L.) as a Source of Dietary Fiber and Antioxidant Compound. CyTA-Journal of Food, 14, 117-123. https://doi.org/10.1080/19476337.2015.1055306

[16] Adeniyi, O.R. and Ayandiji, A. (2014) Economic Analysis of Post Harvest Losses in Plantain (and Banana): A Case Study of South Western Nigeria. British Journal of Applied Science \& Technology, 4, 4456-4467. https://doi.org/10.9734/BJAST/2014/11969

[17] Ruel, M.T. and Levin, C.E. (2001) Discussion Paper 92. Assessing the Potential for Food-based Strategies to Reduce Vitamin A and Iron Deficiencies: A Review of Recent Evidence. Food and Nutrition Bulletin, 22, 94-95. https://doi.org/10.1177/156482650102200115

[18] Chakravarty, I. (2000) Food-Based Strategies to Control Vitamin A Deficiency. Food and Nutrition Bulletin, 21, 135-143. https://doi.org/10.1177/156482650002100205

[19] Gibson, R.S., Hotz, C., Temple, L., Yeudall, F., Mtitimuni, B. and Ferguson, E. (2000) Dietary Strategies to Combat Deficiencies of Iron, Zinc, and Vitamin A in Developing Countries: Development, Implementation, Monitoring, and Evaluation. Food and Nutrition Bulletin, 21, 219-231. https://doi.org/10.1177/156482650002100218

[20] Nwokocha, L.M. and Williams, P.A. (2009) Some Properties of White and Yellow Plantain (Musa paradisiaca, Normalis) Starches. Carbohydrate Polymers, 76, 133-138. https://doi.org/10.1016/j.carbpol.2008.10.012

[21] Ketiku, A.O. (1973) Chemical Composition of Unripe (Green) and Ripe Plantain (Musa paradisiaca). Journal of the Science of Food and Agriculture, 24, 703-707. https://doi.org/10.1002/jsfa.2740240610

[22] Kwofie, M.K., Bukari, N. and Adeboye, O. (2020) Probiotics Potential of Yeast and Lactic Acid Bacteria Fermented Foods and the Impact of Processing: A Review of Indigenous and Continental Food Products. Advances in Microbiology, 10, 492-507. https://doi.org/10.4236/aim.2020.109037

[23] Abou-Zaid, A.A.M., Ramadan, M. and AL-Asklany, S.A. (2011) Utilization of Faba Bean and Cowpea Flours in Gluten Free Cake Production. Australian Journal of Basic and Applied Sciences, 5, 2665-2672.

[24] Miller, R.K. (2017) Chapter 15: The Eating Quality of Meat: V-Sensory Evaluation of Meat. In: Toldra', F., Ed., Lawrie's Meat Science, 8th Edition, Woodhead Publishing, Sawston, 461-499. https://doi.org/10.1016/B978-0-08-100694-8.00015-7 